\title{
The Effect of Knowledge Sharing and Innovation Behavior on The Performance of Batik Entrepreneurs
}

\author{
Nur Laily ${ }^{1}$ and Dyah Poespita Ernawati ${ }^{2}$ \\ ${ }^{1}$ Sekolah Tinggi Ilmu Ekonomi Indonesia (STIESIA) Surabaya \\ ${ }^{2}$ Institut Pemerintahan Dalam Negeri Jatinangor Sumedang. Bandung \\ Email:nurlaily@stiesia.ac.id
}

\begin{abstract}
The purpose of this research was to determine the effect of knowledge sharing and innovation behavior on the performance of Batik entrepreneurs. It was also meant to examine the indirect impact of knowledge sharing on entrepreneurial performance through innovation behavior as a mediator. This is a causality study with 62 batik SME in Surabaya as samples. The inclusion criteria involved batik businesses with a minimum of 3 employees, the enterprise owned by Indonesian citizens, a legal entity, and at least 3 years operation. This research uses primary data with questionnaire and interviews with batik entrepreneurs as data collection instruments. The Partial Least Square (PLS) and Sobel tests to determine the indirect effect of variables. The results showed that knowledge sharing affected the performance of Batik entrepreneurs and their innovation behavior. The Sobel test results showed that innovation behavior mediates the influence of knowledge sharing and entrepreneurial performance.
\end{abstract}

Keywords: Knowledge Sharing, Entrepreneur Performance, Innovation Behavior, Batik SME.

Abstrak: Tujuan penelitian ini adalah untuk mengetahui pengaruh knowledge sharing dan perilaku inovasi terhadap kinerja entrepreneur Batik, pengaruh tidak langsung knowledge sharing terhadap kinerja entrepreneur melalui perilaku inovasi sebagai mediator. Jenis penelitian ini adalah kausalitas. Populasi dan sampel adalah pelaku UMKM batik di Surabaya sebanyak 62 orang, Kriteria yang dipergunakan adalah: usaha batik, memiliki minimal 3 karyawan., usaha milik perorangan,milik warga Negara Indonesia, usaha berbadan hukum atau belum berbadan hukum,usia usaha diatas 3 tahun. Data yang dipergunakan data primer dengan menggunakan instrument penelitian kuesioner dan wawancara pada wirausaha batik. Analisis data menggunakan Partial Least Square (PLS) dan Sobel tes untuk mengetahui pengaruh tidak langsung. Hasil penelitian menunjukkan knowledge sharing berpengaruh terhadap kinerja entrepreneur Batik. Knowledge sharing berpengaruh terhadap perilaku inovasi. Perilaku Inovasi berpengaruh terhadap kinerja entrepreneur UMKM Batik. Hasil uji Sobel menunjukkan Perilaku inovasi mampu memediasi pengaruh knowledge sharing dan kinerja entrepneur.

Kata Kunci: Knowledge sharing, kinerja entrepreneur, perilaku inovasi, UMKM batik. 


\section{INTRODUCTION}

The success of SME depends on entrepreneurs performance. They need to separate personal and business finance to avoid lacking income for investment. The emergence of a knowledge-based economy forces organizations adopts a knowledge management approach (Trivellas et al., 2015). Explicit knowledge can be disseminated, implemented, and developed, increasing individual competence in organizations. (Trivellas et al., 2015) reported that knowledge-sharing culture might develop new general competencies in individuals or sharpen their existing aspects, such as creating new ideas, communicating, interpersonal relationships, prioritizing things, creativity, planning, problem-solving, and team working. This approach is expected to fulfill the information and knowledge needed by the employees to carry out their duties properly and have innovative behavior. According to De Jong \& Kemp (Agustina, 2014), individual behaviors are directed to produce, introduce, and apply new things that are useful at various levels of the organization. Therefore, knowledge sharing is directed at increasing individual performance through innovative behaviors such as making decisions in problem-solving. However, (Wang et al., 2016) reported that it has no direct effect on employee performance, though it is mediated by innovation capability and intellectual capital. It is such differences in the results of previous studies forms the basis of this research. Currently, Surabaya already has around 3,000 SME, a significant improvement from 2010, where they were only 92. According to Risma, A Surabaya Mayor, 98 percent of economic development in Surabaya depends on SME, with large companies having a contribution of only 2 percent (Detikfinance.2016). This is because entrepreneurs were taught to compete through Go Global Go Digital. Batik MSMEs in Surabaya are also proliferating with owners often gathering to discuss and share knowledge on the developments and challenges in business. The implementation of knowledge sharing and innovation behavior helps to deal with global competition. This study therefore aims to determine the following 1). effect of knowledge sharing on entrepreneur performance 2) effect of knowledge sharing on innovation behavior. 3). impact of innovation behavior on entrepreneur performance. 4) indirect effect of knowledge sharing on entrepreneur performance through innovation behavior.

\section{THEORETICAL REVIEW}

Entrepreneurship. Entrepreneurship is the ability of individuals to establish and manage businesses. It involves several activities meant to find, create, and implement work methods, technologies, and new products. In general, entrepreneurship can be achieved by enhancing efficiency in provision of services to earn higher profits. It is the process of creating something different by devoting the time and effort required, dealing with financial, psychological, and social risks, and receiving monetary rewards and personal satisfaction. According to (Alma, 2013), a person in entrepreneurship should have several characteristics, including confidence, task and outcome-oriented, risk-taking, leadership, originality, and be oriented to the future. (Kasmir, 2016) defines an entrepreneur as a brave person in taking risks to open a business in various opportunities. It means having an independent mentality and dare to start a business without being overwhelmed by fear or anxiety even in uncertain conditions. 
Knowledge Sharing. Knowledge Sharing is a process where individuals mutually exchange their knowledge integrated, creating a new understanding. Knowledge is shared between individuals and organizations to develop a common goal for organizations to gain a competitive advantage. According to Hansen (Aulawi et al., 2009) Knowledge Sharing can also be understood as a behavior where someone voluntarily provides access to others regarding their knowledge and experience. The main focus of each individual is to explain, encode, and communicate knowledge to others, groups, and organizations. (Mathuramaytha, 2012) defines it as spreading knowledge and information to colleagues in an organization. In addition to exploiting knowledge to the fullest, it opens up opportunities to explore, obtain, or create new knowledge. Innovation or explorative knowledge sharing is expected to trend in the future. Several other research interprets it as ideas which may be progressively modified or rejected continuously until a shared perspective emerges in tacit and explicit form. Tacit is hidden knowledge not been shared with others, though it is obtained from sense-making and experience. In contrast, explicit knowledge has been shared, communicated, and known by others. The increase in knowledge sharing activities affects individual performance (Wening and Harsono, 2016).

H1: Knowledge Sharing affects entrepreneurs performance.

Innovation Behavior. Innovative work behavior includes the exploration of opportunities and new ideas to achieve increased personal or business performance. Creative behavior involves generating an idea or new thoughts related to products, services, work processes, and procedures. Therefore, innovation is a function of entrepreneurship that can be applied either to business institutions, public (governments) service organizations or to individual/group businesses. Bryd \& Bryman (Laily and Wahyuni, 2018) established the two dimensions that underlie innovative behavior, including creativity and risk-taking. According to Kleysen and Street (Agustina 2014), a person's innovative behavior can be determined using a factor analysis with several dimensions. These include a) exploration of opportunities (paying attention, searching, recognizing and gathering information regarding opportunities); b) direction to produce positive change such as ideas/solutions about opportunities, categories of opportunities, combination of ideas \& information; c) information investigation, which involves trying ideas/solutions. According to (Zohoori and Attarnezhad, 2013), Knowledge Sharing is the process where individuals exchange their knowledge. It is closely related to the improvement of innovative work behavior, which involves a series of steps to improve conduct of workers (Agustina, 2014). The stages include; a) knowing and understanding the scope of work and the potential problems that might occur; b) developing a high awareness of the work quality and creatively striving for action solutions; c) building cooperation and joint commitment to realize innovative improvement in work processes; and d) applying the proposed improvement in the work. Creativity is the ability to develop new ideas and consist of 3 aspects, including expertise, the ability to think flexibly and imaginatively, and motivation from the ability of individuals to innovate. In general, innovation involves the ability to adapt, integrate, and reconfigure all expertise, functional competencies, and resources. Explicit and tacit knowledge sharing has a significant effect on the speed and quality of innovation (Zohoori and Attarnezhad, 2013). Its implementation improves employee innovation capabilities (Asegaff and Wasitowati, 2015). Also, it helps to increase the 
ability of employees to come up with new methods of working and improve work processes for more efficiency and effectiveness.

H2: Knowledge Sharing affects Innovation Behavior.

Entrepreneur Performance. Performance is a product or service created by one or a group of people. Effectiveness and efficiency are the two fundamental dimensions of performance. Primarily, effectiveness refers to fulfilling the needs of customers and stakeholders, while economic efficiency is a measure of how company resources are used. According to (Mathis et al., 2017), performance is basically what workers do or cannot do. Improving the efficiency of both individuals and groups is imperative to enhance organizational performance. Three main factors affect employee performance, including 1) The employee's abilities, such as talent, interests, and personality factors. Skill level is the raw material owned by an employee in the form of knowledge, understanding, ability, interpersonal and technical abilities; 2) An effort from employees such as work ethics, attendance and motivation; and 3) Organizational support, where the company provides facilities for employees, including training and development, equipment, technology, and management. Entrepreneur performance is the efficiency in running the business to achieve their goals. The increased ability of innovation help individuals to overcome problems in work to better the quality and quantity of work. The ability to innovate well leads to the emergence of initiatives to produce a more effective and efficient work method. The better the implementation of knowledge sharing improve process innovation and product quality through the new technology, improving the company's performance (Azadehdel and Jamshidinejad, 2013). The ability to innovate is manifested by trying new ideas, operating methods, and product innovation improves performance (Asegaff and Wasitowati, 2015). According to (Laily and Wahyuni, 2018), The success of female entrepreneurs cannot be separated from the innovation behavior of females, which is based on culture, age, the length of business and experience.

H3: Innovation Behavior affects Entrepreneur Performance. 


\section{Conceptual Framework}

Figure 1. Conceptual framework

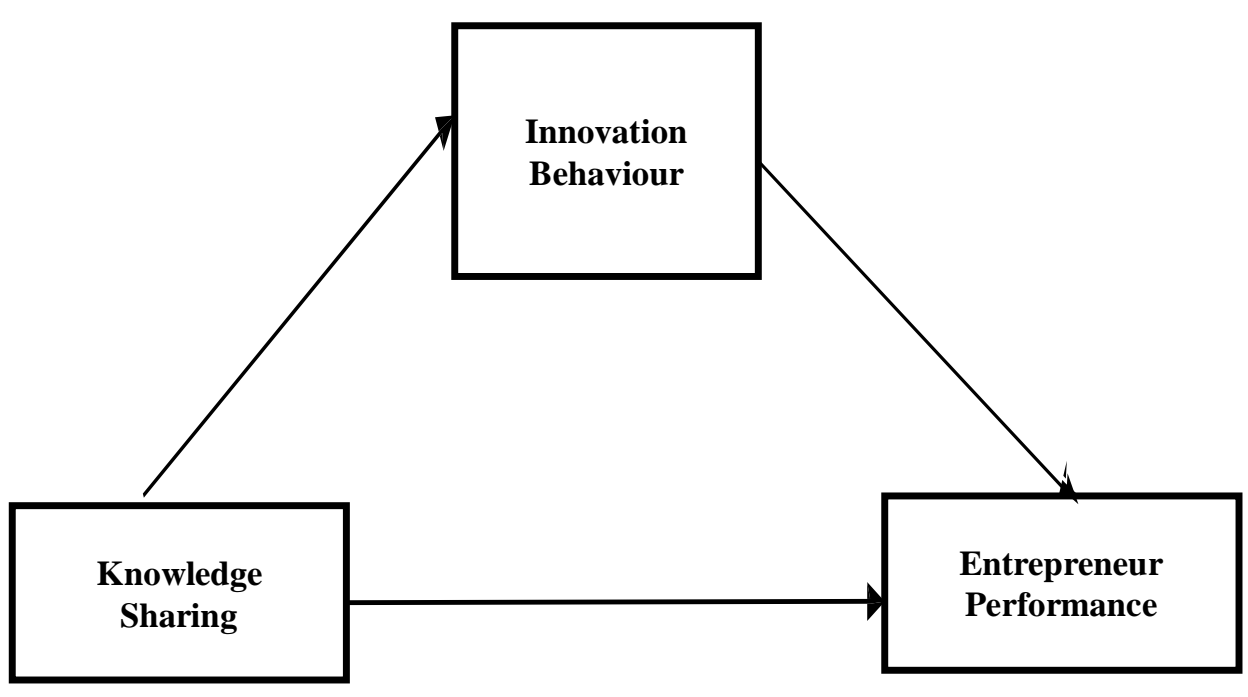

\section{METHODOLOGY}

This is an associative or relationship study using survey methods with the questionnaire as the primary data collection tool. The location of this research was in the Surabaya city, East Java province, in 2019. The population was Batik MSME entrepreneurs, and sampling was carried out by Nonprobability and purposive techniques. The number of samples that met the inclusion criteria were 62 respondents.

\section{Definition of Variable Operations.}

Knowledge sharing is an exchange of knowledge between two or more individuals, where one party communicates it, and the other one assimilates it. The indicator used to determine it was developed by (Harjanti, 2017) in both Tacit and Explicit form.

Innovation Behavior is the ability to introduce, apply, and enhance new ideas that enhance trading. This variable is measured by indicators developed by (Amir, 2015), including Exploration of opportunities, generating ideas, Formative investigation (experiment), Championing (seeking support), and Application.

Entrepreneur Performance is the ability to control trust, build good relationships with customers, and do something meaningful. It is measured using five indicators developed by (Mangkunegora, 2013), including a high personal responsibility, Dare to take and bear the risks faced, having realistic goals. 
Data analysis. Data collection involved distributing questionnaires to respondents in order to get more detailed information about the problem being investigated. The data analysis uses the Partial Least Square (PLS) approach. According to (Ghozali, 2014), PLS help researchers in predictive purposes. The formal model defines latent variables as linear aggregates of the indicators. Weight estimates for creating latent variable score components are obtained based on inner and outer models. To determine the indirect effect, the Sobel test is used.

\section{RESULT}

Description of Characteristics of Respondent Profiles.

Table 1. Respondents Profiles

\begin{tabular}{|c|c|c|c|}
\hline No & SMEs Profiles & Quantities & Percentage \\
\hline 1 & $\begin{array}{l}\text { Gender } \\
\text { - Male } \\
\text { - Female }\end{array}$ & $\begin{array}{l}17 \\
45\end{array}$ & $\begin{array}{l}27,4 \% \\
72,6 \%\end{array}$ \\
\hline 2 & $\begin{array}{cl}\text { Age: } & \\
\bullet & <30 \\
\text { - } & 30-40 \\
\text { - } & 41-50 \\
\text { - } & >50\end{array}$ & $\begin{array}{c}7 \\
17 \\
28 \\
10\end{array}$ & $\begin{array}{l}11,29 \% \\
27,41 \% \\
45.1 \% \\
16,2 \%\end{array}$ \\
\hline 3 & 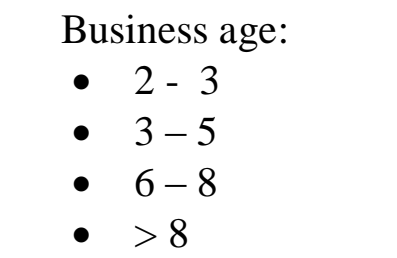 & $\begin{array}{l}16 \\
20 \\
15 \\
11\end{array}$ & $\begin{array}{l}25.8 \% \\
32,2 \% \\
24,3 \% \\
17,7 \%\end{array}$ \\
\hline
\end{tabular}

Source: (Data processed, 2020)

The male and female respondents were $27.4 \%$ and $72.6 \%$, respectively, showing that females still dominate batik SME. Also, 21 of the respondents, or $45.1 \%$, aged from 41 to 50 years. Therefore, the respondents were mature enough to answer the statements on the questionnaire, and most of their businesses had operated for 3-5 years.

Descriptive Analysis. Descriptive statistical analysis is a description or description of data from the minimum and maximum values of each variable, the average value (mean) and the standard deviation value of the research variables. Variables used in this study are knowledge sharing as an independent variable, satisfaction innovation behavior employment as a moderating variable and entrepreneurial performance as a dependent variable. Table 5 is the result of the following descriptive statistical analysis: 
Table 2. Descriptive Statistical Analysis

\begin{tabular}{lcccccc}
\hline & N & Range & Min. & Max. & Mean & $\begin{array}{c}\text { Std. } \\
\text { Deviation }\end{array}$ \\
\hline $\begin{array}{l}\text { Knowledge } \\
\text { Sharing (X) }\end{array}$ & 62 & 12.00 & 8,00 & 20,00 & 15,3387 & 3,82804 \\
$\begin{array}{l}\text { Innovation } \\
\text { Behavior (Z) }\end{array}$ & 62 & 21,00 & 14,00 & 35,00 & 26,5645 & 6,61994 \\
$\begin{array}{l}\text { Entrepreneur } \\
\text { Performance (Y) }\end{array}$ & 62 & 15,00 & 10,00 & 25,00 & 19,2419 & 4,66478 \\
& & & & & & \\
\hline
\end{tabular}

Source: (Data processed, 2020)

Table 5 shows the calculation of descriptive statistics as follows: The number of observations (N) studied were 62 SMEs Batik in Surabaya, Knowledge Sharing Variable (KS) has a minimum value of 8.00 and a maximum value of 20.00 with an average value of 15.3387 with a standard deviation of 3,82804 . Innovation Behavior Variable (PI) has a minimum value of 14.00 and a maximum value of 35.00 with an average value (mean) of 26.5645. While the standard deviation of. 6.61994. The Entrepreneur Performance Variable (KK) has a minimum value of 10.00 and a maximum value of 25.00 with an average value of 19.2419. While the standard deviation of 4.66478

Inferential Analysis using Partial Least Square (PLS). Outer Model'Evaluation. The measurement model test through loading factor is conducted to determine the validity of the indicators by looking at the convergent validity values of the indicators in the model. Each indicator in the model must meet convergent validity which has a value $>0.5$. 
Figure 2. PLS Model

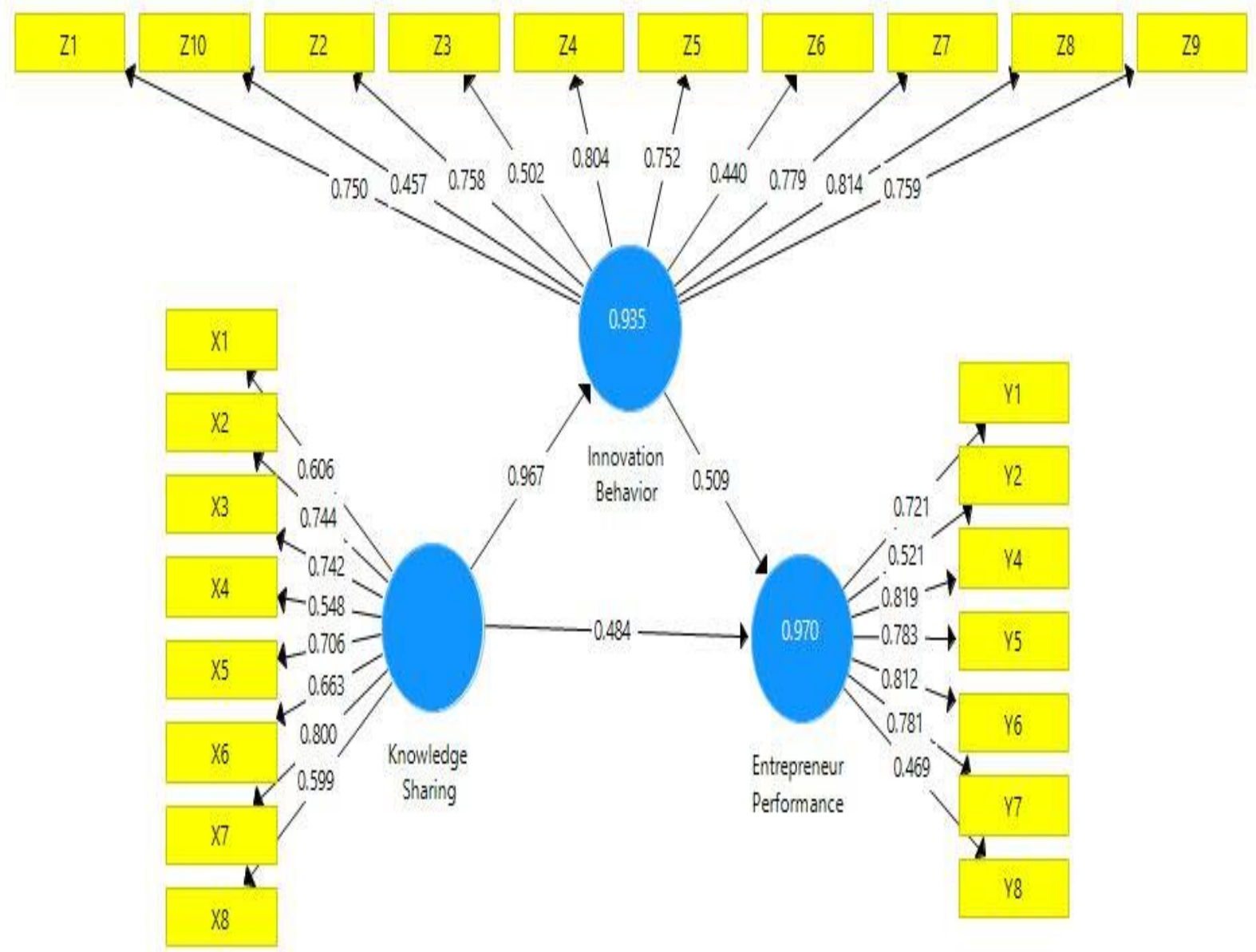

The test results show the direction coefficient for Knowledege Sharing indicators there are 4 indicators whose values are below 0.7 and Innovation Behavior there are 3 indicators showing values below 0.7. Entrepreneur Performance Variable test results there are 3 indicators that indicate values below 0.7, i.e. Then the indicator loading factor below 0.7 must be issued and the data must be reprocessed. The results of the test after a factor loading value below 0.7 are released as follows: 
Figure 3. PLS Model (Result Reprocessed)

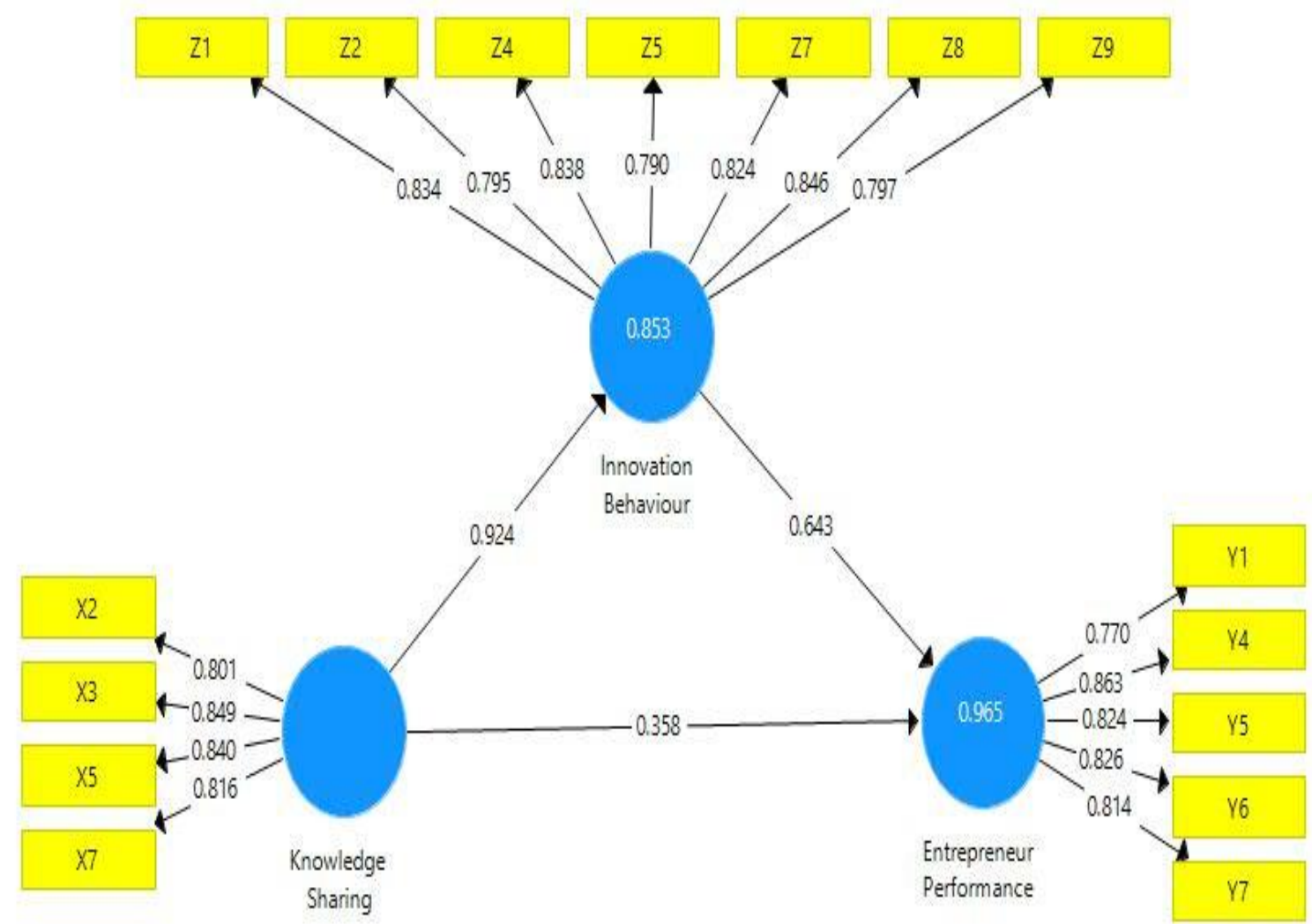

The test results after the factor loading value below 0.7 are issued as follows. Convergent Validity Test; showed that the loading factor or outer loading had a value above 0.7. This means that the indicators used in this research are valid or fulfill the convergent validity.

Table 3. Cross Loading

\begin{tabular}{cccc}
\hline & $\begin{array}{c}\text { Entrepreneur } \\
\text { Performance }\end{array}$ & Knowledge Sharing & Innovation Behavior \\
\hline X2 & 0,829 & 0,801 & 0,821 \\
X2 & 0,792 & 0,849 & 0,778 \\
X5 & 0,759 & 0,840 & 0,745 \\
X7 & 0,759 & 0,816 & 0,700 \\
Y1 & 0,770 & 0,620 & 0,824 \\
Y4 & 0,863 & 0,830 & 0,850 \\
Y5 & 0,824 & 0,782 & 0,745 \\
Y6 & 0,826 & 0,792 & 0,772 \\
Y7 & 0,7814 & 0,864 & 0,796 \\
Z1 & 0,760 & 0,715 & 0,834 \\
Z2 & 0,734 & 0,588 & 0,795 \\
\hline
\end{tabular}




\begin{tabular}{llll} 
Z4 & 0,840 & 0,811 & 0,838 \\
Z5 & 0,791 & 0,828 & 0.790 \\
Z7 & 0,765 & 0,613 & 0,824 \\
Z8 & 0,850 & 0,818 & 0,846 \\
Z9 & 0,811 & 0,857 & 0,797 \\
\hline
\end{tabular}

Source: (Data processed, 2020)

AVE aims to test the reliability of construct variables. AVE aims to establish that the construct variable has a good Discriminant validity value. The AVE value is satisfactory if $>0.5$.

Table 4. AVE and Composite Reliability

\begin{tabular}{lcccc}
\hline & $\begin{array}{c}\text { Cronbach's } \\
\text { Alpha }\end{array}$ & rho_A & $\begin{array}{c}\text { Composite } \\
\text { Reliability }\end{array}$ & AVE \\
\hline $\begin{array}{l}\text { Entrepreneur } \\
\text { Performance }\end{array}$ & 0,878 & 0,880 & 0,911 & 0,672 \\
Knowledge Sharing & 0,845 & 0,846 & 0,896 & 0,683 \\
Innovation Behavior & 0,918 & 0,920 & 0,934 & 0,669 \\
& & & & \\
\hline
\end{tabular}

Source: (Data processed, 2020)

The test results of the discriminant validity are obtained by comparing the value of the Average Variance Extracted (AVE) from each variable with the correlation between them. In case the AVE value is higher than the correlation, the variable has good discriminant validity. It is recommended that these measurements have a value higher than 0.50 . The AVE value on each variable tested is $>0.5$. This shows that all variables in this research fulfill the discriminant validity criteria. Based on the test results, each variable in this research has a value of $>0.70$, and therefore, they all fulfill the construct reliability.

\section{Evaluation of Structural Models (Inner Model)}

Table 5. R-Square $\left(\mathrm{R}^{2}\right)$ Value

R-Square R-Square Adjusted

Knowledge Sharing

\begin{tabular}{lcc}
\hline Entrepreneur Performance & 0,965 & 0,964 \\
\hline Innovation Behaviour & 0,853 & 0,851 \\
\hline
\end{tabular}

Source: (Data processed, 2020) 
Table 5 showed the latent variable of Knowledge Sharing (X) that affects the Innovation Behavior $(\mathrm{Z})$ in the structural model has an $\mathrm{R} 2$ value of 0.853 , indicating that the model is Strong. The latent variables, Knowledge Sharing (X) and Innovation Behavior $(Z)$ that affect Entrepreneur Performance in the structural model, have an R2 value of 0.965 , and therefore, the model is strong.

The suitability of the structural model is shown in the $\mathrm{Q}^{2}$ below.

$$
\begin{aligned}
\mathrm{Q}^{2} & =1-\left[\left(1-\mathrm{RSquare}_{1}^{2}\right)\left(1-\mathrm{RSquare}_{2}^{2}\right)\right] \\
& =1-\left[\left(1-0,853^{2}\right)\left(1-0,965^{2}\right)\right] \\
& =1-[(1-0.728)(1-0.931)] \\
& =1-[(0.272)(0.069)] \\
& =1-[(0.018768)] \\
& =0.981
\end{aligned}
$$

The calculation results show $\mathrm{Q} 2=0.981$, and therefore the model is strong.

Based on the results, Q2 values above zero provide evidence that the model has a strong

\begin{tabular}{|c|c|c|c|c|c|}
\hline & $\begin{array}{c}\text { Original } \\
\text { Sample } \\
\text { Estimate }\end{array}$ & $\begin{array}{c}\text { Mean Of } \\
\text { Subsamples }\end{array}$ & $\begin{array}{l}\text { Standard } \\
\text { Deviation }\end{array}$ & $\begin{array}{c}\text { T - } \\
\text { Statistic }\end{array}$ & P-Value \\
\hline $\begin{array}{c}\text { Knowledge Shari } \\
--> \\
\text { Entrepreneur } \\
\text { Performance }\end{array}$ & 0.358 & 0.363 & 0.083 & 4.325 & 0.000 \\
\hline $\begin{array}{c}\text { Knowledge Shari } \\
---> \\
\text { Innovation } \\
\text { Behaviour } \\
\end{array}$ & 0.974 & 0.925 & 0.018 & 50.620 & 0.000 \\
\hline $\begin{array}{c}\text { Innovation } \\
\text { Behaviour } \\
---> \\
\text { Entrepreneur } \\
\text { Performance }\end{array}$ & 0.643 & 0.637 & 0.081 & 7.895 & 0.000 \\
\hline
\end{tabular}
predicate.

Hypothesis Testing. In this test, the hypothesis directly affects each variable by considering the $t$-static value. In case the value of t-statistics $>t$-table, the variable is deemed to be influential and significant

Table 6. Table Between Constructions

Source: (Data processed, 2020)

Table 6 shows the results of the hypothesis testing: (1) Knowledge Sharing affects Entrepreneurial Performance was accepted (proven). (2) Knowledge Sharing positively affect Behavior Innovation was accepted (proven). (3) Innovation Behavior affect Entrepreneur Performance was accepted (proven). (4) In this research model, there are 
intervening variables, including Innovation Behavior. To determine the indirect effect of Knowledge Sharing on entrepreneur performance through Innovation Behavior, the Sobel test was conducted.

In the Sobel test it can be accepted if the Sobel test produces a t-statistic value> 1.965. The following are the path coefficient values, standard deviations and t-statistics between the effect of Knowledge Sharing on Entrepreneurial Performance through Behavior of innovations generated in Table 7 to be used to calculate the value of a single test.

Table 7. Path Coefficient Value

\begin{tabular}{lccc}
\hline & $\begin{array}{c}\text { Path Coefficient } \\
(\mathbf{b})\end{array}$ & Std. Deviation (SE) & $\mathbf{t}$ - statistic \\
\hline $\mathrm{KS} \rightarrow \mathrm{IB}$ & 0,924 & 0,018 & 50,620 \\
$\mathrm{IB} \rightarrow \mathrm{EP}$ & 0,643 & 0,081 & 7,895 \\
\hline
\end{tabular}

Source: (Data processed, 2020)

Figure 4. Sobel Test Framework

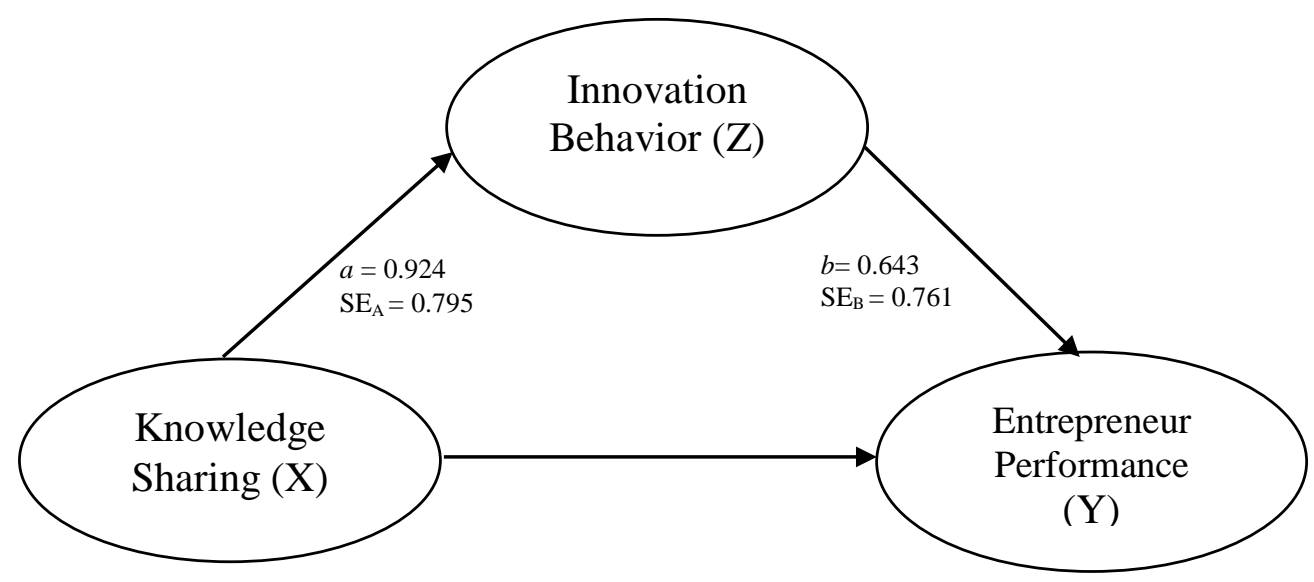

Table 8. The indirect effect of knowledge sharing on entrepreneurial performance

\begin{tabular}{|c|c|c|c|}
\hline Input: & & Test statisti & $p$-value: \\
\hline$t_{a} 50.620$ & Sobel test: & 7.80069259 & 0 \\
\hline$t_{b} 7.895$ & Aroian test: & 7.799207 & 0 \\
\hline & Goodman test: & 7.80217902 & 0 \\
\hline & Reset all & \multicolumn{2}{|c|}{ Calculate } \\
\hline
\end{tabular}




\begin{tabular}{|c|c|c|c|c|}
\hline Input: & & Test statistic: & Std. Error: & $p$-value: \\
\hline a 0.924 & Sobel test: & 7.8450227 & 0.07573362 & 0 \\
\hline b 0.643 & Aroian test: & 7.84356932 & 0.07574766 & 0 \\
\hline$s_{a} 0.018$ & Goodman test: & 7.8464769 & 0.07571959 & 0 \\
\hline$s_{b} 0.081$ & Reset all & & Calculate & \\
\hline
\end{tabular}

Based on these results, Innovative Behavior mediates Knowledge Sharing towards Entrepreneurial Performance with a t-statistic of $7.8950>$ critical value.

\section{DISCUSSION}

The Effect of Knowledge Sharing on Entrepreneur Performance. Knowledge discussion between batik MSME entrepreneurs may improve performance. The sharing activities are carried out every two months, where entrepreneurs meet in a cafe. Discussions to share knowledge and individual experiences evoke ideas, creativity, new methods, and improvements in the batik production process. This is expected to improve the performance of bonded warehouses further and ultimately enhance the business performance of micro-companies. In addition to exploiting knowledge to the fullest, knowledge sharing of batik MSME entrepreneurs can also open up opportunities to explore knowledge to gain or create new knowledge about batik motifs. With this knowledge sharing model, what will happen is the exchange of knowledge between individuals through the formation of a knowledge network that serves to ensure the flow of knowledge. Increased Knowledge Sharing activities will affect individual performance. According to (Maulana et al., 2018), Knowledge Sharing is a voluntary activity that involves spreading knowledge between people or groups in an organization. The results are in line with (Arisanto, 2017), which proved that Knowledge Sharing affects individual performance.

The Effect of Knowledge Sharing on Innovation Behavior. The knowledge sharing approach from an explorative innovation or knowledge sharing perspective is the current trend of knowledge sharing. Knowledge sharing activities include sharing experience and knowledge, will help batik SMEs in solving work problems based on existing experience. Likewise from sharing this knowledge, batik entrepreneurs will get more work knowledge to improve the effectiveness and efficiency of the work process.

Knowledge Management has been implemented in the past year, but its implementation so far is only limited to the introduction and application in a few umkm of batik, not yet involving all SMEs. Experience and knowledge in problem solving, as well as effective and efficient work methods, should be shared with other batik entrepreneurs to help improve performance. Batik entrepreneurs who have the ability to innovate well, have more abilities in solving work problems and accelerating the work process, so that the performance of individual batik SMEs for the better. Knowledge Sharing according to (Wang et al., 2016) is the process by which individuals exchange their knowledge. These activities are closely related to increasing the ability of 
individuals to innovate. Capabilities or capabilities in innovation, namely the ability to adapt, integrate and reconfigure all expertise, functional competencies and resources.

The application of Knowledge Sharing can improve the ability to innovate employees in terms of generating and implementing new ideas or methods in the work process from exchanging information or knowledge . Batik entrepreneurs can share information and knowledge, enhancing innovation behavior. The results showed that batik entrepreneurs have successfully applied knowledge sharing in terms of personal experience and expertise. This helps to enhance innovation behavior to improve work processes, making them effective and efficient. Innovative behavior involves all individual actions directed at the generation, introduction, and application of beneficial novelty at any organizational level (De Jong and Den Hartog, 2010 ). These results are also in line with (Jaberi, 2016), which established that there is a positive and significant relationship between knowledge sharing and innovative behavior. Knowledge sharing has a significant effect on the speed and quality of innovation (Zohoori and Attarnezhad, 2013).

The Effect of Innovation Behavior on Entrepreneur Performance. Increased ability to innovate, will help individuals in overcoming problems in work, so that the quality and quantity of work can be better. With the ability to innovate well will help the emergence of initiatives to produce work methods that are more effective and efficient. The better the application of knowledge sharing will improve process innovation and product quality through the use of new technologies, the company's performance will increase (Azadehdel and Jamshidinejad, 2013). The ability to innovate which is manifested in the form of always trying new ideas, trying new operating methods, product innovation, will be able to improve performance (Asegaff and Wasitowati, 2015). Innovation behavior affects entrepreneurs' performance. In general, better innovation enhances company performance. Innovation helps companies to develop ideas about new products, focus on efforts production, and always strive to sell varied items in the market. The innovations made can be a significant foundation for competitive advantage in the long term. The entrepreneurs had made efforts to use innovation business activities. It helps to develop new products and make modifications in the market, enhancing survival chances. This is in line with (Laily and Wahyuni, 2018), which established that innovation behavior influences the success of female batik entrepreneurs.

The Indirect Effect of Knowledge Sharing on Entrepreneur Performance through Innovation Behavior. The Sobel test showed Innovation Behavior mediates Knowledge Sharing on Entrepreneurial Performance. This test showed the entrepreneurs' performance might be better in case knowledge sharing is supplemented with innovation behavior. MSME entrepreneurs in Surabaya develop and modify their products and markets through innovation behaviour, enhancing their survival. Therefore, it is necessary to have a culture of knowledge sharing between batik entrepreneurs so that information about the development of the external environment and from inside can be spread throughout the entire batik community, so that the knowledge that is owned by each entrepreneur is not buried within each. With the knowledge sharing culture like this, Batik SMEs can quickly find out about developments in the current economic conditions and can adapt to changes in the environment that are felt more quickly. Good knowledge management can improve 
employee performance, namely by sharing knowledge, so company performance will indirectly increase and have a competitive advantage. Through knowledge sharing a maximum exploitation of knowledge will occur. Utilization of knowledge that spreads to all members of the organization or all units within a company, is certainly far more maximal than the exploitation of knowledge by certain individuals or certain units. Optimal use of certain organizational knowledge or competencies will increase the company's competitiveness. In addition to exploiting knowledge to the fullest, knowledge sharing can also open up opportunities to explore knowledge to gain or create new knowledge and innovation

According to (Wang et al., 2016), knowledge sharing has no direct effect on employee performance, though it is mediated by innovation capability and intellectual capital.

\section{CONCLUSION}

This study established that knowledge Sharing affects Entrepreneurial Performance. The SMEs entrepreneurs organized meetings and discussions which enhanced performance. Additionally, knowledge sharing has a significant effect on Behavior Innovation, which also enhances entrepreneur performance. The use of innovation in business activities develop new products and make modifications to the market. This increases the chances of survival and improves performance. Furthermore, Knowledge Sharing has an indirect effect on Entrepreneurial Performance through innovative behavior. It has a significant impact on performance if supplemented with innovation behavior. Innovative behavior has helped batik SME entrepreneurs develop products and make necessary modifications.

\section{REFERENCES}

Agustina. T. S (2014). Mengungkap Perilaku Inovatif 3 Etnis Wanita Pedagang di Surabaya. Jurnal Manajemen Teori dan Terapan, 7 (1) 23-37.

Amir, M. T. (2015). Validation of Innovative Behavior as A Multidimensional Construct. Jurnal Manajemen Teknologi Vol.14,No.1: 66-78.

Arsitanto. D. B. (2017). Pengaruh Knowledge sharing Terhadap Individual Innovation Capability Dan Kinerja Karyawan. Jurnal EMBA.5(2).1539-1545.

Asegaff, M. and Wasitowati. (2015). Knowledge Sharing Sebagai Sumber Inovasi dan Keunggulan Bersaing Pada Usaha Mikro Kecil dan Menengah (UMKM) Sektor Batik. Jurnal UNISSULA Teknik Ekonomi . 2 (1) . 208 - 221.

Aulawi, H., G., Suryadi., and I. Sudirman. (2009). Hubungan Knowledge Sharing Behavior dan Individual Innovation Capability. Jurnal Teknik Industri. 11(2): 174-187.

Azadehdel, M, R and M. A Jamshidinejad. (2015). The Relationship between Knowledge Sharing, Innovation, and Performance. Interdisciplinary Journal Of Contemporary Research In Business 5.(5). 408 - 412.

Detikfinance (2016). Risma: Dulu Ada 92 UKM di Surabaya, Sekarang 3.000 Lebih. https://finance.detik.com/berita-ekonomi-bisnis/d-3149875. 
De Jong, J. P. J., and Den Hartog, D. N. (2010). Measuring Innovative Work Behaviour. Creativity and Innovation Management, 19(1), 23-36.

Ghozali. I. (2014) Structural Equation Modeling Metode Alternatif dengan Partial Least Squares (PLS). Semarang.Badan Penerbit Universitas Diponegoro.

Harjanti, D and, Noerchoidah. (2017). The Effect Of Social Capital And Knowledge Sharing On Innovation Capability. Jurnal Manajemen Dan Kewirausahaan, Vol .19, No 2: 72-78.

Jaberi, E. (2016). The Effect Of Knowledge Sharing On Innovative Behavior Among Employee Of Besat Hospital In City Of Hamedan. International Academic Journal of Accounting and Financial Management, 3(4), 41-47.

Kasmir. (2016). Kewirausahaan Edisi Revisi. Jakarta. Rajawali Press.

Laily, N., and D.Wahyuni (2018) The Key Success Female Entrepreneurs Batik Jonegoro in Indonesia. International Journal of Business Administration. 9 ( 2), 67-79.

Mangkunegara, A, P. (2013). Manajemen Sumber Daya Manusia Perusahaan. Bandung: Remaja Rosda Karya.

Maulana. F., Sularso. A., dan Titisari. P (2018). Analisis Pengaruh Knowledge Sharing Dalam Penerapan Sistem Manajemen Mutu Iso 9001:2008 Terhadap Kinerja Inovasi Dan Kinerja Karyawan. Jurnal Manajemen Dan Kewirausahaan. 6(1).57-69.

Mathis. R .L., J. H. Jackson., S. Valentine., and., Meglich. P. (2017). Human Resouce Management. 15th Edition, Boston, MA Cengage Learning.

Mathuramaytha, C. (2012). Developing Knowledge-Sharing Capabilities Influence Innovation Capabilities in Organizations-a Theoretical Model. In International Conference on Education and Management Innovation IPEDR (Vol. 30).

Trivellas, P., Akrivouli, Z., Tsifora, E., Tsoutsa, P. (2015). The Impact of Knowledge Sharing Culture on job Satisfaction in Accounting Firm with Mediating Effect of general Competencies. E-journal Procedia Economic and Finance Elsevier. 19: 238-247.

Wang, Zhining, Sharma, P.N., Cao, J. (2016). From Knowledge Sharing to Firm Performance: A Predictive Model Comparison. Journal of Business Research. Elsevier. 69: 4650-4658.

Wening, Nur and Harsono, Mugi. (2016). Relationship between knowledge sharing to individual Performance. International Journal of Research in Business Management Vol. 4, Issue 1: 67 - 78.

Zohoori, Mahmood and Attarnezhad, Omid. (2013). The relationship between knowledge sharing and innovation in electronic industry of Iran. Interdisciplinary Journal of Contemporary Research In Business Vol 5, No 1: 722- 729. 